\title{
ANALIZA NORMALNIH NAPONA U ZONI OTVORA NA ČELIČNOM STUBU VETROGENERATORA
}

\author{
Aleksandar Landović ${ }^{1}$ \\ Miroslav Bešević ${ }^{2}$ \\ Danijel Kukaras ${ }^{3}$
}

УДК: 624.014.2.074.6

DOI: 10.14415/konferencijaGFS 2015.038

Rezime: U radu je prikazana analiza normalnih napona u zoni otvora na dnu čeličnog stuba - nosača vetrogeneratora. Dat je prikaz varijantnih/mogućih načina ojačavanja u zonama maksimalnih normalnih napona. Takođe, prikazana je kontrola napona za usvojeno rešenje čeličnog stuba.

Ključne reči: Normalni napon, čelični stub, koncentracija napona, otvor.

\section{UVOD}

U radu je prikazano rešenje ojačavanja zone oko revizionog otvora na dnu čeličnog stuba - nosača vetrogeneratorske turbine. Detaljan proračun glavne noseće konstrukcije prikazan je u [2]. Idejnim građevinskim projektom su obuhvaćeni noseći čelični stubovi vetrogeneratora proizvođača VESTAS tip V112 3MW za potrebe izgradnje Vetroparka "Kovačica". Vetropark bi trebao da se nalazi u opštini Kovačica, u blizini naselja Padina, Crepaja i Debeljača. Visina glave rotora je 119.0 m (osovinski), a visina stuba na koji se ona oslanja je $116.8 \mathrm{~m}$. Poluprečnik elise rotora je $56.0 \mathrm{~m}$, tako da maksimalna ukupna visina objekta sa vrhom elise iznosi $175.0 \mathrm{~m}$.

Pri proračunu dejstva vetra na čeličnu konstrukciju stuba korišćene su osnovne brzina vetra koje odgovaraju proračunskim kombinacijama opterećenja:

- NLC - Normal load cases /ALC - Abnormal load cases: $V_{\text {hub }}=28.75 \mathrm{~m} / \mathrm{s}$.

- NO - Normal operation: $\mathrm{V}_{\text {hub }}=27.21 \mathrm{~m} / \mathrm{s}$,

- NP - Normal production / ES Emergency stop - equivalent $V_{\text {hub }}=23.13 \mathrm{~m} / \mathrm{s}$

Uticaji usled vetra na vetrogenerator - gondolu i rotor, koji deluju na vrhu stuba dobijeni su od strane proizvođača.

\footnotetext{
${ }^{1}$ Asistent mr Aleksandar LANDOVIĆ, dipl.građ.inž., Univerzitet u Novom Sadu, Građevinski fakultet Subotica, Kozaračka 2a, tel:024/554-300, ladovic1@gmail.com

${ }^{2}$ Profesor dr Miroslav BEŠEVIĆ, dipl.građ.inž., Univerzitet u Novom Sadu, Građevinski fakultet Subotica, Kozaračka 2a, tel:024/554-300, miroslav.besevic@gmail.com

${ }^{3}$ Profesor dr Danijel KUKARAS, dipl.građ.inž., Univerzitet u Novom Sadu, Građevinski fakultet Subotica, Kozaračka 2a, tel:024/554-300, danijel.kukaras@gmail.com
} 
Glavna noseća konstrukcija vetrogenaratora je čelični stub kružnog poprečnog preseka, promenljivog po visini. Stub je konzolnog sistema, uklješten u kružni armirano-betonski temelj izveden na šipovima. Noseća čelična konstrukcija stuba sastoji se iz pet montažnih komada, različitih dimenzija.

Na prvom montažnom komadu je predviđen otvor za ulaz u stub. Zbog koncentracija napona i promene graničnih uslova u pogledu izbočavanja cilindrične ljuske, pored povećane debljine plašta cilindra sa $44 \mathrm{~mm}$ na $75 \mathrm{~mm}$ u ovoj zoni su predviđena podužna i poprečna ukrućenja po obodu otvora, kao i ojačanja debljine plašta u zoni najvećih koncentracija napona u uglovima otvora. S obzirom na dimenzije poprečnog preseka (odnos prečnik/debljina zida plašta) stub je tretiran kao cilindrična ljuska. Proračun uticaja u stubu je sproveden na linijskom modelu, ali su naponi u zoni otvora za vrata na MK1 određeni primenom metode konačnih elemenata sa shell elementima. Proračunske vrednosti dejstava su određene na osnovu kombinacija koje su definisane u IEC 61400-1. Na osnovu merodavne kombinacije uticaja izvršena je kontrola nosivosti poprečnih preseka prema EN1993-1-1 i kontrola stabilnosti cilindrične ljuske na izbočavanje, prema EN1993-1-6. Treba naglasiti da je proračun stabilnosti na izbočavanje sproveden sa početnim imperfekcijama - klasa B.

\section{RAČUNSKO ISTRAŽIVANJE}

Otvori u čeličnom plaštu izazivaju poremećaj trajektorija napona, (Slika 1.), što ima za posledicu koncentraciju napona koji mogu u značajnoj meri prekoračiti vrednosti kako dopuštenih, tako i napona na granici tečenja. U zonama oko otvora mogu se javiti i problemi sa lokalnim izbočavanjem preseka kao posledica previsokih napona pritiska.

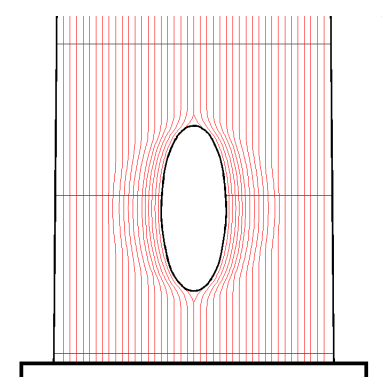

Slika 1. Trajektorije napona u zoni oko otvora prema [1]

Moguća rešenja problema koncentracije normalnih napona i napona izbočavanja prikazana, su prema [1], na slici 2. Ojačavanje zone oko otvora najčešće se izvodi dodavanjem vertikalnih, horizontalnih, prstenastih ukrućenja, ili njihovom kombinacijom, kako bi se sprečilo izbočavanje lima usled napona pritiska. Na prekoračenje dopuštenih normalnih napona može se uticati ugradnjom krutog prstenastog ojačanja po celom obimu otvora, kao i lokalnim povećanjem debljine zida čelične cevi. 


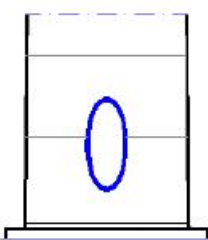

a

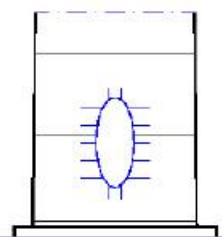

b

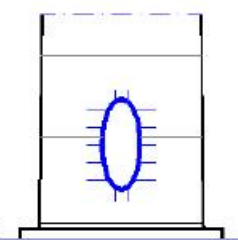

C

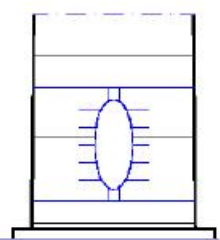

d

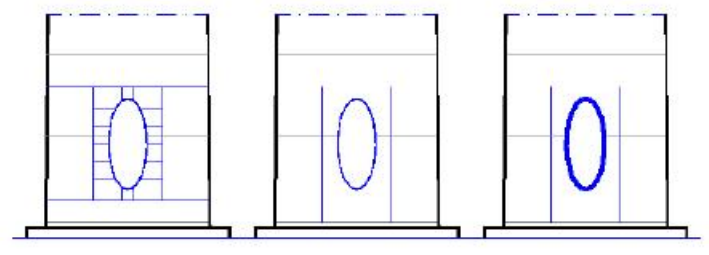

e

f

g

Slika 2. Mogući načini ojačavanja zone oko otvora

Na slici 3a prikazano je stanje normalnih napona za slučaj kada ojačanje zone oko otvora nije vršeno. Ovo je slučaj kada se u čeličnoj cevi napravi otvor bez ikakve dalje intervencije. Uočava se da u su uporedni naponi u čeliku prekoračili napon od 500MPa. Vrednost uporednog napona određen je iz Von Mises-ovog uslova najveće energije distorzije. Ovako rešenje nije bilo prihvatljivo, te je s toga u narednoj varijanti izvršeno ukrućenje otvora ubacivanjem krutog prstena po celom obimu otvora. Na slici 3b prikazani su normalni naponi nakon ojačavanja otvora upravno postavljenim prstenom. Detalj ojačanja prikazan je na slici 5.
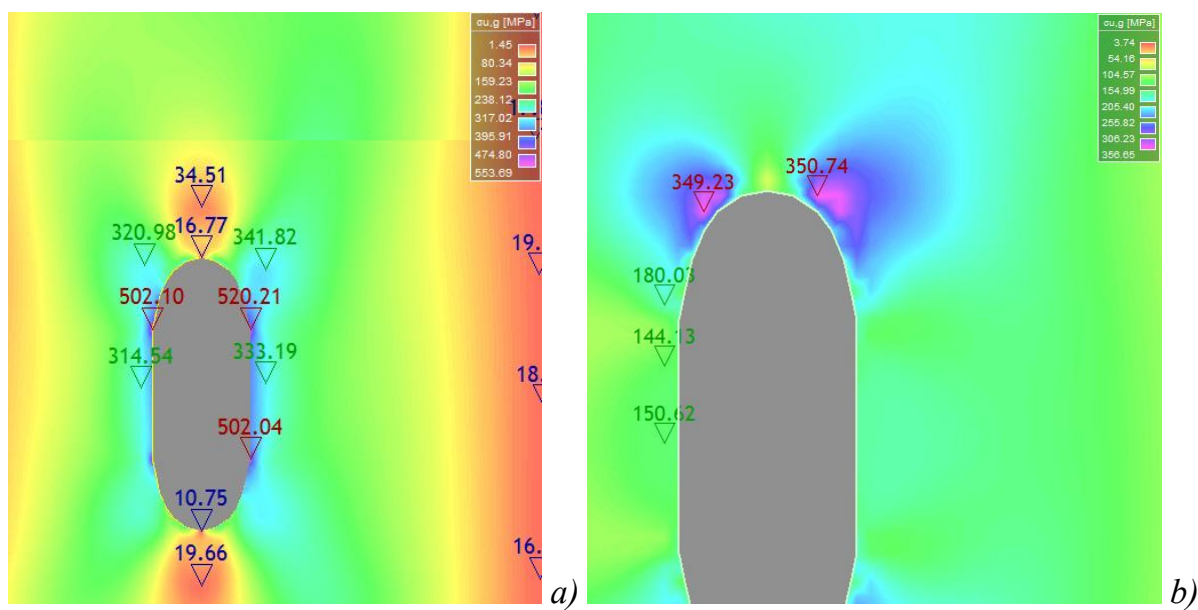

Slika 3. Stanje napona u zoni oko otvora

Dodavanjem ojačanja maksimalni normalni naponi su značajno umanjeni, mada su i dalje preko $350 \mathrm{MPa}$. Zato je u narednom koraku izvršeno dodatno ojačavanje u vidu 
povećanja debljine zida čeličnog plašta. Ovo ojačanje je izvršeno u zoni od $800 \mathrm{~mm}$ oko otvora. Na slici 4 prikazano je stanje uporednih normalnih napona za usvojeni slučaj ojačanja zone oko otvora na stubu.

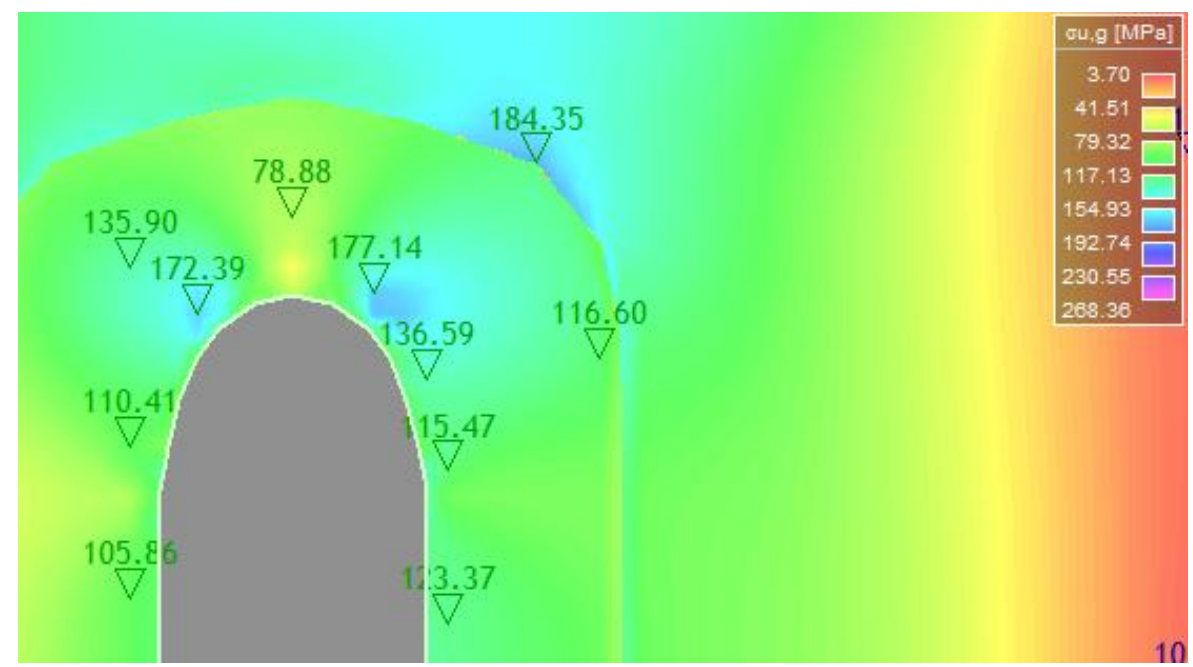

Slika 4. Stanje napona u zoni oko otvora za usvojeno rešenje

Analizom stanja napona prikazanih na slici uočava se da maksimalni naponi u ovom slučaju nisu prekoračeni. Na slici 5 prikazano je konačno - usvojeno rešenje ojačavanja zone oko otvora.
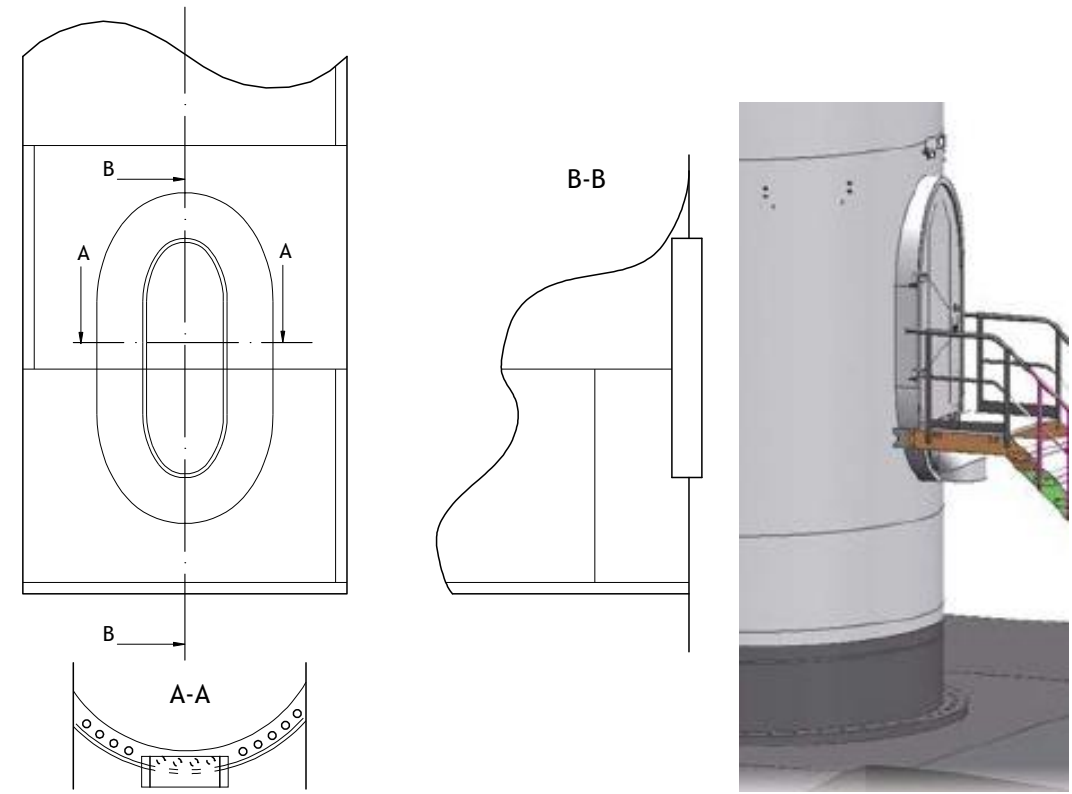

Slika 5. Usvojeno rešenje ojačanja zone oko otvora 


\section{ZAKLJUČCI}

U skladu sa preporukama [1] za ojačavanje zone oko otvora kontrolisana su varijantna rešenja. Zbog ograničenog prostora $u$ ovom radu nisu prikazane sve analizirane kombinacije, ali se navode uočeni zaključci:

- maksimalni efekti ojačavanja ostvareni su dodavanjem krutog prstena po celom obimu otvora, čime se znatno umanjuju koncentracije normalnih napona.

- dodavanje vertikalnih, horizontalnih ili kosih ukrućenja oko otvora nije značajnije uticalo na promenu vrednosti normalnih napona.

- povećanje debljine plašta se pokazalo kao dobro rešenje za snižavanje koncentracije normalnih napona, kao i za povećavanje dopuštenih napona pri izbočavanju, međutim ovo rešenje nije uvek praktično zbog ekonomskih i tehničko - tehnoloških aspekata.

\section{LITERATURA}

[1] C. Baniotopoulos, I. Lavasas, G. Nikolaides, P. Zervas: Stiffeners to the door opening of the tower - WP3.4. RFS-CT-2006-00031 - HISTWIN High-Strength Steel Tower for Wind Turbine, Background document, Institute of Steel Structures Aristotle Univ. of Thessaloniki, Greece, 2009.

[2] Bešević M., Tešanović A., Kukaras D., Landović A.: Proračun i dimenzionisanje noseće čelične konstrukcije stuba vetrogeneratora, Zbornik radova Građevinskog fakulteta br.26, Subotica, 2014.

[3] Bešević M., Tešanović A., Kukaras D., Landović A.: Vetropark "Kovačica" - Idejni projekat čelične konstrukcije stuba vetroturbine, Projektni biro Elnos BL i Geoput, Beograd, 2013.

\section{ANALYSIS OF NORMAL STRESSES IN VICINITY OF THE OPENING ON WIND TURBINE STEEL TOWER}

Summary: This paper presents the analysis of normal stresses at vicinity of opening on the bottom of steel wind turbine tower. Review of possible methods for strengthening maximal normal stresses zones is presented. Also, detail strass analysis is presented for adopted solution for steel column.

Keywords: Normal stress, steel tower, stress concentration, opening. 